\title{
Experimenting with Transmutation: Darwin, the Beagle, and Evolution
}

\author{
Niles Eldredge
}

Published online: 28 November 2008

(C) Springer Science + Business Media, LLC 2008

\begin{abstract}
Detailed analysis of Darwin's scientific notes and other writings from the Beagle voyage reveals a focus on endemism and replacement of allied taxa in time and in space that began early in the journey. Though it is impossible to determine exactly when Darwin became a transmutationist, the evidence suggests that he was conversant with the transmutational ideas of Lamarck and others and testing ("experimenting" with) them-before he received a copy of Lyell's Principles of Geology, vol. 2, in November 1832, in which Lyell describes and disputes Lamarck's theory. To the two rhea species of Patagonia and the four mockingbird species of the Galapagos, we can now add the living Patagonian cavy (rodent) species, and its extinct putatively related species that Darwin collected at Monte Hermoso (Bahia Blanca) in the Fall of 1832, as a replacement pattern absolutely critical to the development of Darwin's transmutational thinking. Darwin developed his first transmutational theory by adopting "Brocchi's analogy" (Rudwick 2008)-i.e. that births and deaths of species are analogous to the births and deaths of individuals. Births and deaths of species, as of individuals, are thus explicable in terms of natural causes. Darwin explored these themes and the replacement of the extinct cavy by the modern species explicitly in his February 1835 essay (Darwin 1835a).
\end{abstract}

Keywords Charles Darwin · Transmutation · The Beagle

When on board H.M.S. 'Beagle,' as naturalist, I was much struck with certain facts in the distribution of the

\footnotetext{
N. Eldredge $(\bowtie)$

American Museum of Natural History,

New York, NY, USA

e-mail: epunkeek@amnh.org
}

inhabitants of South America, and in the geological relationships of the present to past inhabitants of that continent. These facts seemed to me to throw some light on the origin of species - that mystery of mysteries, as it has been called by one of our greatest philosophers. (Darwin 1859).

With these words, Charles Darwin opened On the Origin of Species, one of the most important contributions in the history of science - or perhaps in western culture in its entirety so far. For it was the Origin, of course, that finally and forever established as a serious, thoroughly scientific theory, evolution - the idea that all organisms that have ever lived on earth have descended from a common ancestor in the remote geological past.

Why Darwin? How did a young, rudimentarily trained naturalist come to be convinced of what was then usually called "transmutation?" For though (as we will see in perhaps surprising detail at the conclusion of this essay) Darwin was aware of the transmutational notions of his grandfather Erasmus and the thoughts, as well, of the French zoologist Lamarck - he was at least as keenly aware of the religious precepts prevalent in the England of his birth in 1809 - precepts that saw the origin of species as the primal act of the Creator. And though Darwin was aware that British science was imbued with the search for natural causes underlying natural phenomena (Rudwick 1985), when it came to the origin of species, his teachers at Cambridge University, like most other British scientists of the 1820 s, still steadfastly looked away from transmutation.

What brought Darwin to transmutation in the first place is more than an interesting historical question: I address it here in a journal devoted to communicating evolutionary science because the answer to the Why and How of Darwin's initial adoption of evolution reveals the patterns in nature and the underlying logic of their 
interpretation that cuts to the heart of scientific observation, analysis, and synthesis. Darwin's story on the Beagle tells us why and how evolution is a credible and truly scientific theory.

I have come to see Darwin's biological, paleontological, and geological work aboard the Beagle as imbued with the spirit of experimentation. I will make the case that Darwin framed his work as if he were fully aware of both sets of possibilities - creationism on the one hand and transmutation on the other. The essay is in two parts. Using Darwin's first two sentences of On the Origin of Species as a testable hypothesis (i.e., did he really do what he said he did?), I develop a linear examination of Darwin's relevant work as naturalist on the Beagle. For this, I rely primarily on Darwin's (largely unpublished) Geology Notes ("Diary"), read with Prof. David Kohn over several weeks of study at Cambridge University Library, Cambridge, England. Other primary sources include Darwin's letters (especially, though not exclusively, to his mentor Rev. John Stevens Henslow at Cambridge), his Diary (Keynes 1988), and his Zoology Notes (Keynes 2000) and additional sources cited below.

My analysis of Darwin's work on the Beagle raises some further intriguing questions, most especially Where did Darwin get the approach to comparing fossil species with their living counterparts he used from the very inception of the Voyage? And where did he get his focus on patterns of replacement in space and in time of closely similar species (e.g., "congeneric" species—-species belonging to "allied groups") that were endemic ("peculiar") to South America. I will address these issues in the second part of this essay.

\section{Early Days on H.M.S. Beagle}

Charles Darwin was a month and a half shy of his 23rd birthday when the HMS Beagle finally left Plymouth Harbor on December 27, 1831. He brought with him an unbridled enthusiasm for the outdoors, a love for shooting birds, and a passion for collecting rocks, minerals - and especially beetles. For several years, he had dreamed of visiting the tropics, inspired by the exploits of the German explorer/scientist Alexander von Humboldt. The Captain, Robert FitzRoy, had accepted Darwin as unpaid ship's naturalist and personal companion-and hoped that Darwin would spend much of his time on land locating economically valuable mineral deposits while the Beagle plied the coastal waters of either side of southern South America, producing more accurate navigational charts than those they shipped out with.

Darwin had, in addition, what could only be described as a modicum of formal training in field geology and, especially, systematic botany. It was the geology that was to pay off first, when the Beagle made its first stop at St.
Jago in the Cape Verde Islands in January 1832. There, Darwin found fossils in a band of limestone exposed along the beach - fossils that seemed to him to belong to the very same species whose shells he beachcombed. There was even a faint trace of coloration left on the fossil mollusk shells. Darwin wrote in his notes:

To what a remote age does this in all probability call us back \& yet we find the shells themselves \& their habits the same as exist in the present sea. (Darwin 1832a)

This was the first of what would prove to be a typical Darwinian experience on the Beagle voyage, combining keen insight with a chance observation. Darwin had most likely experienced long-extinct Paleozoic fossils in his field excursion with his geological mentor Adam Sedgwick just months before departing on the Beagle. But here, he had fossils so young that they clearly belonged to the same species still living in the shallow waters offshore. And though his notes reveal his rapidly growing interest in geology (as it seemed remarkable to Darwin that the uplift of the limestone band in the geological past was not so remote that it could hold the fossilized traces of still-living species), with those fossils, Darwin actually had in his hands a part of the history of modern, living species. He was not the first naturalist to observe the fossilized remains of living species, but this was his own first encounter-one that set the tone and tenor of most of his experiences with ancient animal remains for the next three years in southern South America.

The Beagle reached Bahia on the northeast coast of Brazil in late February 1832. Darwin's famous remark in his Diary - "the mind is a chaos of delight" (Keynes 1988, p. 42) - when he finally got his longed-for first glimpse of riotous tropical vegetation, marked a switch in his priorities. Throughout the nearly five-year long journey, Darwin was quick to work on whatever Nature presented most vividly to him. Aboard ship, Darwin would trawl for plankton, collecting marine invertebrates and fish. In St. Jago, it was geology and fossils. Here, in Brazil, it was the diversity of tropical ecosystems, and by the time the Beagle reached Rio de Janeiro, Darwin was up and running, beginning his trip-long task of collecting plants, birds, mammals, insects, and other terrestrial invertebrates.

In his notes, Darwin wrote "I could not help noticing how exactly animals \& plants of each region are adapted to each other." He also decided that a slug-like creature he collected in the forest was not a mollusk (true slug), after all, but rather a terrestrial flatworm - a conclusion disputed by his other mentor, John Stevens Henslow-in a running argument that was to take place desultorily over the next several years in the vagaries of long-distance correspondence. Darwin was rapidly gaining enough confidence in 
his naturalist skills that he could enter into a civil, but emphatic, disagreement with his teacher.

The flatworm incident (protracted as it was) marks the first time Darwin is captured explicitly analyzing the zoological affinities of a species he has collected. Since at least the time of Linnaeus in the mid-eighteenth century, zoologists (and their botanist counterparts) had accepted the existence of "natural groups" and had recognized that some such groups show greater "affinity with" or "relatedness to" one group rather than another: rodents, such as beavers and mice, for example, appeared to be a natural group, as did carnivores (like wolves and cats) - yet all seemed to belong to the same natural group "mammals." These were the nested groupings ("taxa") of progressively more related species that formed the Linnaean hierarchy. Darwin's focus on such groups - and particularly those whose geographic range seemed restricted to South America-blossomed with his formative experiences with both fossil and living species at Bahia Blanca in Patagonia in September and October 1832. There can be no doubt that this first visit to Bahia Blanca was as important to the development of Darwin's thinking as his far better-known and celebrated visit to the Galapagos Islands nearly three years later-in September and October 1835.

\section{Bahia Blanca, September and October 1832}

Probably the most important of all of Darwin's varied scientific experiences at Bahia Blanca was the treasure trove of both vertebrate and invertebrate fossils Darwin discovered at two localities: Monte Hermoso and Punta Alta. As Darwin wrote Henslow:

...in the same formation I found a large surface of the osseous polygonal plates.... Immediately I saw them I thought they must belong to an enormous Armadillo, living species of which genus are so abundant here (Darwin 1832b).

Darwin actually hedged his bets on whether the sheet of "osseous polygonal plates" did in fact come from a species of extinct, giant armadillo - as he was aware of a recently published paper claiming them to have covered the body of an extinct species of giant ground sloth. But Darwin's first impression as recorded in his letter to Henslow turned out to be correct: these huge extinct glyptodonts are indeed giant armadillos; more importantly, whenever Darwin subsequently mentions these plates of armor in his notes (he was to find more during the subsequent two years exploring Patagonia), he nearly always remarks on how armadillo-like they seem.

Darwin also had the bones of giant ground sloths - and the several species of large mammals whose fossils he collected at Bahia Blanca were all apparently extinct (though Darwin (1832c) wrote a passage in his geological notes speculating that a large creature said to be alive in the wilds of Patagonia might turn out to be a surviving giant ground sloth; he later crossed these notes out as fantasyyet stories persist to the present day of the possible existence of giant sloths in South America). Thus, Darwin saw that modern members of a group (the armadillos and sloths belong to what was then called the Edentata) of allied forms can replace extinct species.

The large fossil bones at Punta Alta were intermingled with the shells of invertebrates belonging to species that Darwin thought were still living in the waters just offshore (as he had previously observed at St. Jago); though the large mammals were presumably all extinct, the presence of their fossil remains alongside the shells of living species of marine invertebrates clearly showed that none of these fossils were, geologically speaking, very old:

The cemented gravel...contains numerous organic remains: $1^{\text {s. }}$ shells there are so numerous as in places, especially the upper bed, almost to compose it; they appear to me to be exactly the same species which now exist on the beach: And it is to be especially remarked the proportional numbers of each species are about the same; the most abundant in both cases are Crepidula Voluta...\& Venus; the rarest. Pecten Fissurella \&c. $-2^{\text {d. }} 2$ Coralls. an encrusting Flustra \& an Ostrea. these both appear identical with what now exist: $-3^{\mathrm{d}}$ a piece of wood converted into calcareous matter (Darwin 1832c).

At the other locality in Bahia Blanca-Monte Hermosothe geological strata and mode of preservation and occurrence of fossils was somewhat different from Punta Alta. At Monte Hermoso, Darwin collected small bones of what he identified as a cavy or agouti- one of the larger species of rodents belonging to a group native to South America:

I could perceive traces of 4 or 5 distinct animals: two of which certainly belonged to the Rodentia. One must have been allied to the Agouti; the tarsi \& Metatarsi belong to an animal less than the present common inhabitant, Cavia patagonica.

(b)The Agoutis are all proper to S. America; \& none have hitherto been found in a fossil state:-To conclude with the organic remains I have shown that some of the bones probably belong to the Edentata. \& that the osseous plates are supposed to belong to the Megatherium.-(Darwin 1832c)

The cavy fossils (Fig. 1) turn out to have been as important to the development of Darwin's thinking as the Galapagos mockingbirds - as we will see as the story 


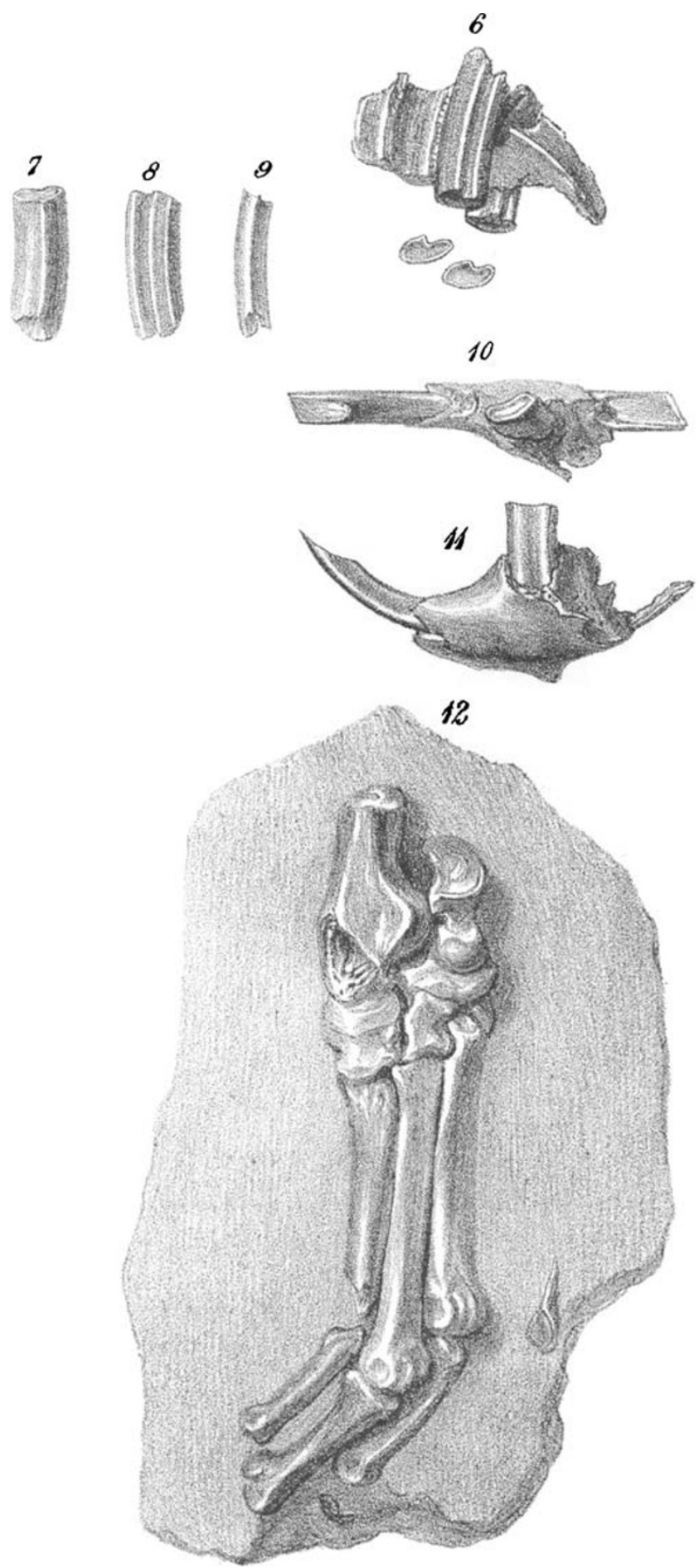

Fig. 1 Darwin's small rodent fossils from Monte Hermoso. Figures 6-12 of Plate XXXII of Richard Owen's (1840) monograph on Darwin's fossil vertebrates collected while on the Beagle voyage (in Darwin 1840)

unfolds. For the moment, I simply note that Darwin sees the Monte Hermoso cavy as "lesser than" the modern species; he also duly notes that agoutis are all "proper to South America" (the living Patagonian cavy_or "mara"-is not a species of agouti; here, as elsewhere, what Darwin thought is the important issue-i.e., and not whether his conclusions on the affinities of fossil and recent species agree with modern taxonomy). And that Darwin was concerned that the cavy fossils at Monte Hermoso were in fact of the same age as the richly fossiliferous beds at Punta Alta, with their large extinct edentate mammals and their still-living species of fossil invertebrates, consider his words to Henslow in the letter already quoted; referring to his collection of fossil vertebrates at Bahia Blanca, Darwin writes:

If it interests you to unpack them, I shall be very curious to hear something about them:- Care must be taken, in this case, not to confuse the tallies. (Darwin 1832b).

Just why Darwin is worried that the labels on his fossil specimens from Bahia Blanca might be lost or "confused" becomes starkly clear as events unfold later in the Beagle voyage.

This was a lot to discover all at once. Darwin was pointing to the replacement of extinct members of a natural group by living members-perhaps not the first to have written about such a pattern of replacement in time (the Frenchman Georges Cuvier had written about species of fossil and living elephants) but probably the first to note the extinction of some species and their replacement by "closely allied" modern species while collecting specimens in the field (Darwin was also collecting and eating the living armadillos).

Important, as well, is Darwin's emphasis on groups of animals that seem to be restricted to South America. Darwin never used his examples of fossil invertebrate species in his speculations, as he was never quite sure how widely distributed those species were (except in the case of the giant Patagonian oyster-apparently extinct but not replaced by an obvious living descendant).

Darwin was evidently not sure that the living species of sloths and armadillos - all members of the mammalian Order Edentata, a "natural group" already recognized by Linnaeus-are restricted to South America (with the exception of North American armadillos). [In 1837, when he had been back in London for nearly a year, Darwin asked zoologist George Waterhouse to jot down a list of the world's living species of Edentata; Waterhouse erroneously (i.e., in terms of our modern understanding) added five Old World species to the 19 South American species]. The Edentata (in a more restricted sense now known as the Xenarthra) have long since been known to be strictly American. Regardless of the uncertainty about the distribution of edentates as a whole, Darwin was certainly aware that armadillos are only known from the Americas.

And Darwin was right in his supposition that the agoutis and cavies are restricted ("endemic") to the western 
hemisphere. He was to repeatedly emphasize that fact as his ideas developed as he continued his travels in South America.

And so began Darwin's focus on replacement patterns of species within natural groups - with a strong emphasis on groups of species only known from that particular corner of the world. That way, there was no possibility that the species could have come in from somewhere else. Whatever was causing the disappearance of species and however the replacement species appeared, it all had to happen right there in the region where he was collecting their bones and shells.

None of which makes Darwin a transmutationist while at Bahia Blanca. But he was already narrowing down the possibilities when he started - then and there - to focus on replacement in time of species belonging to endemic natural groups. In effect, Darwin had begun performing a thought experiment on the extinction - and appearance — of species.

But, as if all that were not enough, Darwin also encountered a species of large, fierce, and very poisonous snake: the fer-de-lance, identified by Darwin as a Trigonocephalus and now known as Bothrops-almost certainly the species Bothrops alternatus still common around Bahia Blanca (Dr. Teresa Manera, personal communication; see Fig. 2). As he wrote in his Diary for October 8, 1832:

I also caught a large snake, which at the time I knew to be venomous; but now I find it equals in its poisonous qualities the Rattle snake. In its structure it is very curious, and marks the passage between the common venomous and the rattlesnakes. Its tail is terminated by a hard oval point, \& which, I observe, it vibrates as

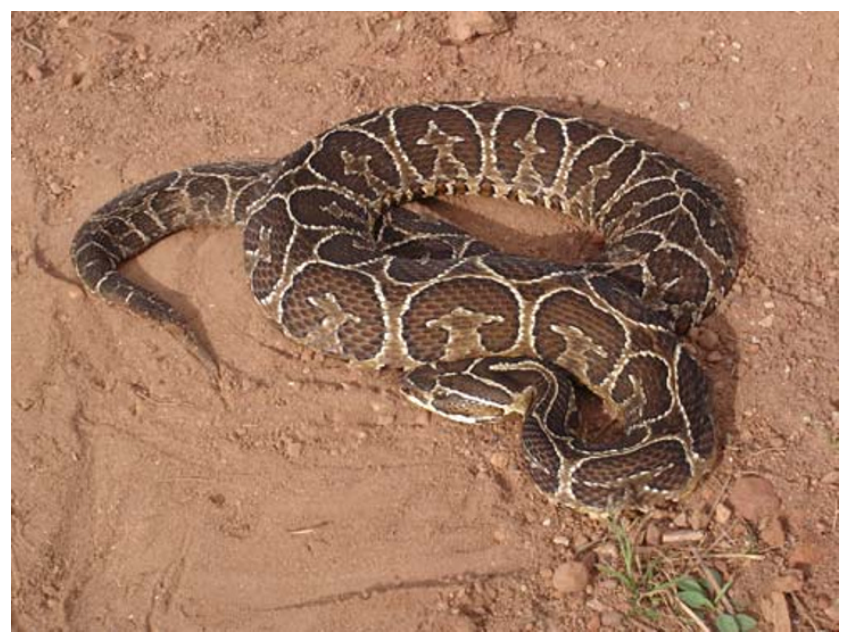

Fig. 2 Bothrops alternatus. The tip of the tail that attracted Darwin's attention as "mark(ing) the passage" between the tails of adders and rattlesnakes is clearly shown in this photograph kindly provided by Dr. Pedro H. Bernardo of the Museu de Zoologia, Universidade de São Paulo those possessed with a more perfect organ are known to do so." [emphasis added] (Keynes 1988, p. 109).

In his Zoological Notes, Darwin (Keynes 2000, p. 91) wrote "how beautifully does this snake both in structure \& habits connect Crotalus \& Vipera," and says nearly the same thing in his letter to Henslow (Darwin 1832b).

How evolutionary this sounds to modern ears! And yetif for no other reason than he is saying this to HenslowDarwin is unlikely to have been writing these words on his fer-de-lance as an already-committed transmutationist.

One other observation at Bahia Blanca is worth noting: Darwin records in his notes and in that same letter to Henslow a bird that is, to his eyes, a strange mixture of features:

So much for the dead \& now for the living.- - there is a poor specimen of a bird, which to my unornithological eyes, appears to be a happy mixture of a lark pidgeon \& snipe.... Mr MacLeay himself never imagined such an inosculating creature.... I suppose it will turn out to be some well-known bird although it has quite baffled me. (Darwin 1832b)

MacLeay was the author of the Quinarian System, which held that natural groups come in bunches of fivewith overlapping connections between them. Once again, Darwin was grappling with apparent mixtures of features ("inosculating") which to him seem to involve several otherwise distinct groups of birds ("lark pidgeons and snipes"). And once again, the twin, related themes of relationships among taxa, on the one hand, and the occurrence of particular anatomical features - not unlike the snake example-reveals this harbinger of full-blown evolutionary thinking.

\section{Lyell and Principles of Geology Vol. 2}

But science does not rest solely on observation-no matter how intense and fraught with implications those observations may be. If science is an interplay between the natural world and the human mind (both imaginative and analytical), then the thoughts of others who have seen similar things assume great importance. Darwin, as a young, inexperienced, and only partially trained naturalist, was wary of his lack of expertise - one reason why scholars (e.g., Sulloway 1982) have argued that Darwin was not committed to transmutation until after he arrived home and heard the opinions of experts such as John Gould on his bird collections, Richard Owen on his fossil mammals, and George Waterhouse on the living mammals collected while on the Beagle. 
But there was a decent library of natural history books on board from the onset of the expedition, and more were added as the journey went on. As the days and months went by, Darwin's reading, coupled with his hands-on field experiences, contributed to a palpable growth in confidence in his own abilities - including his speculations on what all these observations might really mean. He grew more expert in bird identification, for example-going from applying European names to South American species and genera (often erroneously, sometimes even consciously so), to adopting local names instead-and finally, by trip's end, becoming familiar with the published ornithology of western hemisphere birds-including the families utterly endemic to the region. And, likewise, as his confidence grew, he came to dispute some of the points held dear in the minds of his old mentors-like Henslow - and newly adopted role models - especially Charles Lyell.

When the Beagle set sail, Darwin had with him Vol. 1 of Lyell's three-volume work Principles of Geology (Lyell 1830). Darwin had written in pencil on the fly leaf "Gift of Capt. FitzRoy." Precious (and disappointingly!) few other annotations in Darwin's hand can be found in the pages of this book - in great contrast to Darwin's penchant as he grew older to make voluminous notes and commentary in most of the books he read-including later editions of Lyell's Principles. Again, the young, tentative Darwin seemed unwilling to deface the works of his teachers. Darwin appears to have read Lyell's first volume as soon as he received it - applying its geological lessons, along with the practical, if brief, field experience he had had with Sedgwick in Wales in August 1831, when he examined the fossilbearing strata of St. Jago and Bahia Blanca.

But Lyell's Vol. 1 was less a manual on how to do geology than what geology — in Lyell's eyes - had concluded so far about the nature and history of the earth, including its living inhabitants. And, as much as Darwin began to see South American geology through Lyellian eyes (he was especially drawn to Lyell's penchant for seeing topographic changes as a consequence of a series of relatively minor uplifts, rather than one enormous cataclysm - a view that he continued to hold through his theory of the uplift of the Andes and its inverse - the formation of coral atolls around submerging sea mounts) and as respectful as Darwin remained of Lyell throughout his life (they became friends in the 1840s, Lyell becoming one of Darwin's inner circle), from almost the beginning, Darwin seems comfortable taking issue with Lyell. For example, Darwin had the fossil bones of terrestrial mammals mixed in with the shells of marine invertebrates at Bahia Blanca. And as his peregrinations took him several times into the Patagonian interior, he found several places where bones of the "giant armadillos" and other large extinct mammals were jumbled together-very much as if they were deposits of carcasses of many dead animals swept away by a flood (though Darwin always distanced himself from declaring such deposits the vestiges of the Biblical Flood). Lyell was primarily arguing against the probability of finding the remains of terrestrial vertebrates in a marine setting but in general was loath to accept any catastrophic explanations for geological phenomena.

How welcome, then, the arrival of Lyell's newly published Vol. 2 of the Principles must have been to Darwin. In his copy, Darwin inscribed the words "Charles Darwin M: Video, Novemr. 1832" - not long after the Beagle had left Bahia Blanca (the ship went directly to Montevideo, where Darwin records receiving letters from home on October 24th; they then went on to Buenos Aires, returning to Montevideo in November-where Darwin crates his specimens for shipment home but with no mention of any more letters or packages from home).

Lyell's second volume is both an explication, and a refutation, of Lamarck's theory of transmutation. Here, it is commonly assumed, is where Darwin got his first full understanding of Lamarck's views-for even though Lyell can barely suppress arguing point by point with Lamarck even as he summarizes Lamarck's theory, it is in fact a fairly accurate characterization of Lamarck's theory. As others have pointed out, Lyell was a barrister - and Vol. 2 especially reads like a lawyer's brief-against transmutation. (Secord 1997, p. xxxii, has written that Lyell was in contention for a position in geology at King's College - and that one of the electors about to name the successful applicant was an Anglican Bishop who had recently written that geologists were beginning to undermine "beliefs concerning the creation of man and the reality of a universal Deluge").

How quickly Darwin devoured Lyell's second book on transmutation - and what he made of it-is impossible to say. Darwin is silent on Lyell's views on transmutation, in his Diary, notes, and letters - until his essay "February 1835"-with one exception: Lyell accepts extinction of species as a real phenomenon. Lyell believes that, on average, one species per year becomes extinct the world over. Extinction of species is staggered, then - not coming in episodes of many species in a given ecosystem dying off at the same time. And, Lyell says, though God knows how long a species will exist-when, that is, the species is destined to become extinct-nonetheless, species die off through natural causes - which to Lyell generally meant physical causes, such as environmental change. Seeing extinction as a natural process was to play an important role in Darwin's thinking - and it was a phenomenon that some of his own data had a bearing on. But, again, he was not to address the subject directly until nearly the end of the Beagle's sojourn on the east coast of South America.

Lyell was convinced that species diversity remained more or less constant throughout geological time-thus 
naturally had to confront the origins ("creations" to Lyell's mind) of new species. To keep things in balance, Lyell felt that, on average, over the world's ecosystems, one new species appeared every year. Yet, to his mind, these were not "replacements"- extinctions and replacements occurred at different times in different ecosystems. Steering very clear from the subject of "allied forms," Lyell instead suggested an ecological pattern to the appearance of new species: after all, he wrote in one passage, a new carnivore species cannot be created unless a suitable prey species is already present.

[As a measure of how carefully Darwin read Lyell (through all editions-not just while on the Beagle), Darwin wrote to Lyell in 1844 - complaining that Richard Owen was claiming authorship of the "Law of Succession" of extinct and modern allied species - and reminding Lyell that he (i.e., Lyell) had himself noted such sequences in his discussion of extinct and living species of marsupials in Australia. Yet, on the whole, Lyell saw the "creation" of new species predominantly in ecological terms rather than as sequences of replacement of allied species - the way Darwin always tended to see them].

\section{Fieldwork, 1833-Early 1834: The Geographic Replacement of Species}

Meanwhile, field work went on. After an excursion down the coast that took the Beagle all the way down to Tierra del Fuego and with a brief stop in the Falkland Islands (renamed by the British after they seized the Malvinas
Islands from Argentina in 1828), the Beagle turned back north. When Darwin reached Maldonado in Uruguay in May 1833, there was little geology to be seen, so he put his helpers to work shooting as many birds in the vicinity as they could set their sights on. It was to pay off handsomely, coloring his observations throughout the remainder of the trip - as these birds served as the baseline for comparisons with the birds he saw on both sides of southern South America and on adjacent islands-including his critical encounters on the Galapagos more than two years later.

Though he used generic names familiar to him from England for the most part (admitting his use of Lanius, a shrike, was in most instances almost undoubtedly wrong), he also used names of birds endemic to the New Worldsuch as Icterus and Furnarius. Funariids are "oven-birds," often observed in open spaces on the ground and thus much easier to see than birds of the thick forests. Immediately, Darwin began to draw comparison between, e.g., Furnarius rufus and another species he had seen at Bahia Blanca - of which he also says "I do not believe this bird is found South of R. Negro." The very next time Darwin makes an entry on Furnarius in his zoological notes, he is further south, along the Patagonian coast, in Port Desire, six months later (January 1834). Here, he says the Furnarius in the bushes "takes the place" of one of the species he collected at Maldonado.

Replacement again - but now in space, rather than in time: one closely allied species "takes the place" of another living elsewhere. And though they may be similar in habits (their behavior in bushes, for example), the key here is that they are also close, congeneric relatives. Later, towards the
Fig. 3 a Greater rhea (photo by Niles Eldredge). b John Gould's drawing of "Darwin's rhea"the smaller southern species (American Museum of Natural History [AMNH] Library). Plate XLVII, in Darwin (1838)
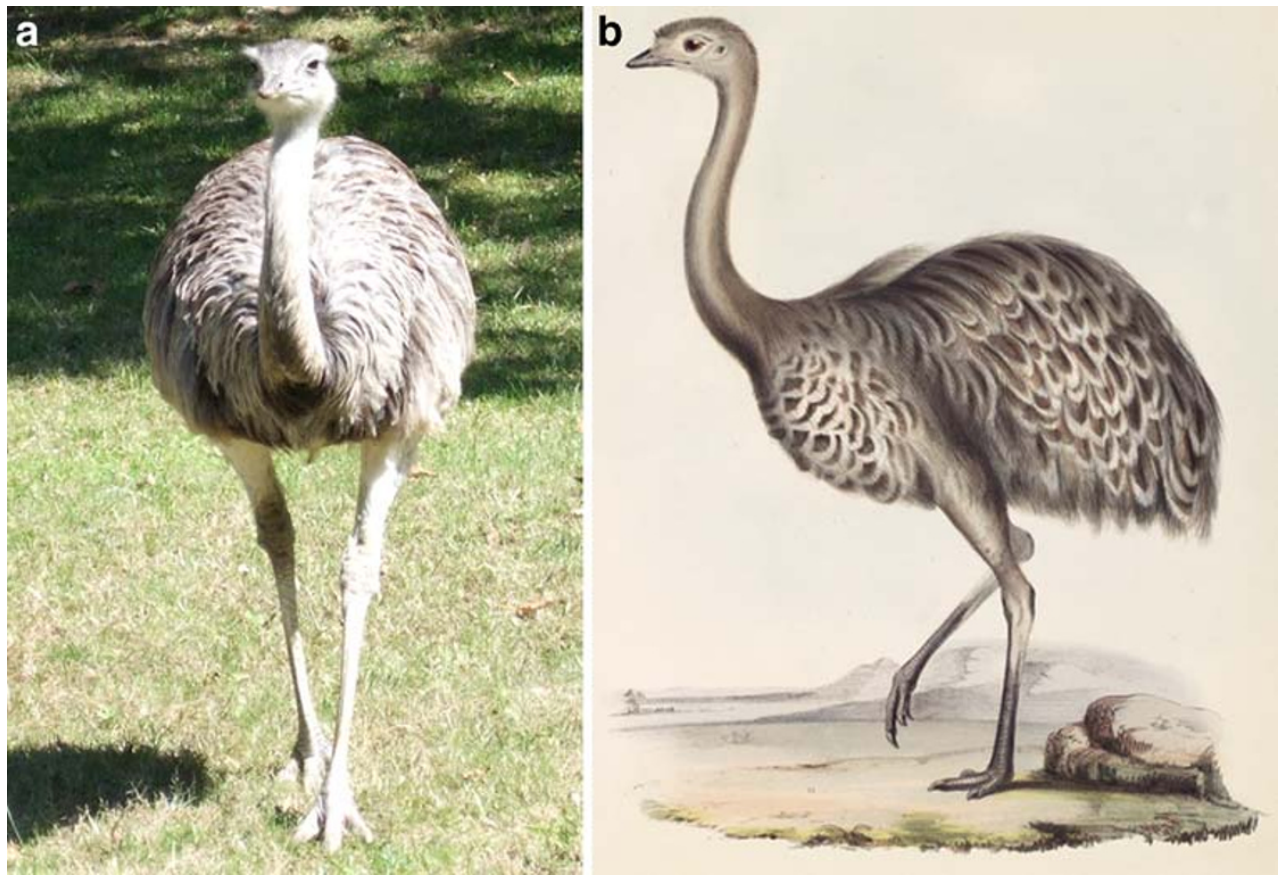
very end of the voyage, when Darwin is writing up his Ornithological Notes which make clear that he already has become a transmutationist (Kohn et al. 2005), he rewrites and consolidates all these notes - using phrases like "takes the place" with even greater frequency. But he was on to this form of replacement - where one closely allied species replaces another in a different area-as soon as he started collecting birds after Maldonado.

The prime example of geographic replacement in Darwin's mind and experience was the two species of rheas - the large ostrich-like birds of the open plains (Fig. 3). He had encountered the common rhea at Bahia Blanca, and he appends an (undated) note to his discussion of the common rhea, saying he had first heard of another, slightly smaller species when visiting the Rio Negro that, he believes, does not occur north of the Rio Negro-the "Avestruz Petisse." It would not be until Christmas Day, 1833 that Darwin actually saw his first specimen - shot by the artist Conrad Martens and served as part of Christmas dinner. Darwin was to see them in the wild in the future-all south of the Rio Negro and venturing up into the southern Andes. Together with the Furnarius and a few other examples - all birds - the rheas became the quintessential example of geographic replacement of closely allied species as Darwin approached, and eventually completely embraced, the transmutationist hypothesis (see Fig. 4).

The Beagle had anchored at East Falkland Island in March of 1833, but it was not until its return to the Falklands a year later that Darwin extended - and refinedhis pattern of geographic replacement of closely allied species. This time, it was a mammal: the (now-extinct) Falkland fox.

In his notes, Darwin says that the Gauchos and Indians all had assured him that the Falkland fox is native to, and endemic on, the Falkland Islands - which to Darwin is "indisputable proof of its individuality as a species-It is very curious thus having a quadruped peculiar to so small a tract of country" (2000, p. 209). Darwin adds a note (taken by the editor of the published notes, R.D. Keynes, to have been written while Darwin was still there on the Falklands): "Out of the four specimens of the Foxes on board, the three are darker and come from the East; there is a smaller \& rusty coloured one which comes from the West Island: Lowe [a whaling captain] states that all from this island are smaller \& of this shade of color" (Keynes 2000, p. 210). Not only is this species different from any of the other species of fox on the mainland but it appears to be somewhat different on each of the two main islands.

Thus by March 1834, Darwin had extended his interest in seeing replacement patterns among closely "allied," endemic species to a group of offshore islands-and had seen replacement-within-replacement as distinct forms of this "individual" species take the place of one another on the East and West Falkland Islands.

\section{The Earthquake Portfolio: "Reflection" and "February 1835"}

In Darwin's papers housed in the archives of Cambridge University Library, the "Earthquake Portfolio" stands out, containing as it does the two surviving essays Darwin is known to have produced while on the Beagle. The earliest of these, entitled "Reflection on reading my Geological notes" (Darwin 1834a), is reckoned by historian Sandra Herbert (Herbert 1995, 2005) to have been written sometime around March 1834-right after the Beagle left the Falklands, and was still plying the southern coastal
Fig. 4 An old atmospheric rendition of life on the Patagonian plains, replete with Patagonian cavies, rheas, and other species (AMNH Library)

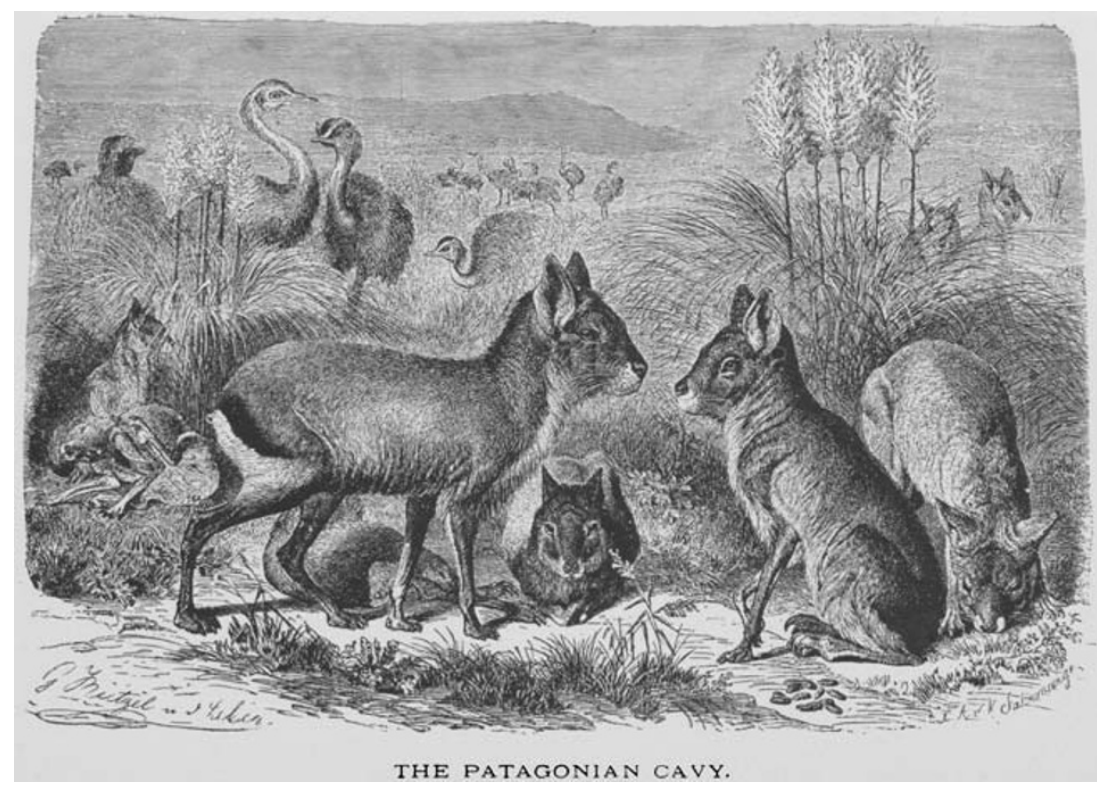


waters of eastern South America. Herbert (1995) provides a transcription of the entire document.

In this essay, Darwin is trying to summarize a coherent understanding of the sequence of events that shaped not only the present-day topography but the deposition of the Tosca and other beds-especially those containing the invertebrate and vertebrate fossils he had discovered over the preceding two and a half years. Herbert thinks the essay was written just after Darwin visited Port St. Juliancollecting the bones of what he thought at the time was a species of Mastodon. In the essay, Darwin concludes that the semi-desert-like conditions of present-day Patagonia were already in place when the St. Julian mastodon and all the other large extinct mammals whose bones he had first encountered at Bahia Blanca were roaming the countryside. "But then we have the puzzle how could these most sterile plains support such large animals: The very same puzzle \& explanation of occurrence, refers to the bones at Port St. Julian" (Darwin 1834a).

Darwin is not to develop the implications of this conclusion - that the environment had not changed substantially since the time of the now-extinct large South American mammals, for what then drove them extinct?until his second essay in the Earthquake Portfolio - simply entitled "February 1835" (Darwin 1835a). But he did, in an annotation to this 1834 essay, take issue with Lyell's assumption that extinction takes place in a regular, gradual manner the world over-allowing geologists to correlate beds (i.e., conclude they were formed at about the same time) if they have similar ratios of extinct and still-living species. Once again, we see Darwin gaining his own intellectual voice, daring to challenge - at least in his private notes - the views of senior, often renowned naturalists.

It is in the essay "February 1835" where Darwin takes his most incisive step away from received wisdom-openly toying with transmutation, and indeed arguably, if perforce exceedingly subtly, all but declaring his adoption of transmutationalism. The historian M. J. D. Hodge (1983) has published and discussed this short essay - and the full text is scheduled to be posted on the "Darwin Digital Library" at http://darwinlibrary.amnh.org/. The most critical passages are quoted here for convenience.

The main thrust of the "February 1835" essay is, again, the sequence of geological events of Patagonia-but now with a far greater focus on the history of the fossil species, especially the large extinct mammals that Darwin had encountered there, than was the case of his geological essay of a year earlier. The "February 1835 " essay begins:

The position of the bones of Mastodon (?) at Port St Julian is of interest, in as much as being subsequent to the remodelling into steps of what at first most especially appear the grand (so called) diluvial covering of Patagonia.-It is almost certain that the animal existed subsequently to the shells, which now are found on this coast. I say certain because the 250 \& 350 \&c plains, must have been elevated into dry lands when these bones were covered up \& on both these plains abundant shells are found. We hence are limited in any conjectures respecting any great change of climate to account for its former subsistence \& its present extirpation. In regard to the destruction of the former large quadrupeds, the supposition of a diluvial debacle seems beautifully adapted to its explanation; in this case however, if we limit ourselves to one such destructive flood, it will be better to retain it for the original spreading out of the Porphyry pebbles from the Andes. (Darwin 1835a).

Darwin is saying two important things here - that there is no one single "diluvial" event recorded here to explain the extinctions (again, as against the standard assumptions of Biblically based geology); and, more significantly, that there is no reason to suppose that the extinctions were due to a major change in climate. It is this latter point that sets up the truly novel — and transmutationally imbued — comments that immediately follow:

With respect then to the death of species of Terrestrial Mammalia in the S. part of S. America. I am strongly inclined to reject the action of any sudden debacle.Indeed the very numbers of the remains render it to me more probable that they are owing to a succession of deaths, after the ordinary course of nature.-As $\mathrm{M}^{\mathrm{r}}$ Lyell (a) supposes Species may perish as well as individuals; to the arguments he adduces. I hope the Cavia of B. Blanca will be one more small instance, of at least a relation of certain genera with certain districts of the earth. This co-relation to my mind renders the gradual birth \& death of species more probable.

The "(a)" after "Mr Lyell" in the above quote refers to a note Darwin added:

(a) The following analogy I am aware is a false one; but when I consider the enormous extension of life of an individual plant, seen in the grafting of an Apple tree, \& that all these thousand trees are subject to the duration of life which one bud contained. I cannot see such difficulty in believing a similar duration might be propagated with true generation.--If the existence of species is allowed, each according to its kind, we must suppose deaths to follow at different epochs, \& then successive births must repeople the globe or the number of its inhabitants has Varied exceedingly at different periods.-A supposition in contradiction to the fitness, which the Author of Nature has now established. 
Scholars have long puzzled over-and debated - these words. Many (e.g., Herbert 2005 and especially M.J.S. Hodge 1983 - who in my opinion has produced the best discussion of "February 1835 " to date) have sensed more than a hint of transmutation in this brief essay-yet without fully grasping the full meaning of it all. For example, referring to his own interpretation, Hodge (1983, p. 22) says that “....although we cannot be sure that this was exactly Darwin's reasoning in this passage...," we can at least be certain that Darwin disagrees with Lyell on the causes of extinction.

But there is much more to these passages than the clear break with Lyell over extinction. Based on what we have seen so far concerning Darwin's biological and paleontological work on the Beagle, what Darwin is actually doing - for the first time explicitly-is describing the actual pattern, not only of the deaths of species, but of their births as well. Whether or not he has by this time fully adopted the transmutational position, at the very least by "February 1835 ," he is taking it very seriously as an explanation of the births of species in terms of natural causes.

The importance of Darwin's explicit analogy between the deaths of individuals and the deaths of species cannot be overemphasized. Darwin had, in his notes on the Falkland foxes, referred to the "individuality" of that species. At stake here is nothing less than the origin of Darwin's transmutational views - as made explicit two years later in the second half of the famous "Red Notebook" (Darwin 1836a-1837; see Herbert 1987) - and revealed, albeit in retrospect, in November 1844, in a letter to the Rev. Leonard Jenyns (Henslow's brother-in-law and one of the several naturalists invited to join the Beagle prior to Darwin's being asked). As Darwin wrote to Jenyns:

With respect to my far-distant work on species, I must have expressed myself with singular inaccuracy, if I led you to suppose that I meant to say that my conclusions were inevitable. They have become so, after years of weighing puzzles, to myself alone; but in my wildest day-dream, I never expect more than to be able to show that there are two sides to the question of the immutability of species, ie whether species are directly created, or by intermediate laws, (as with the life \& death of individuals). I did not approach the subject on the side of the difficulty in determining what are species \& what are varieties, but (though, why I sh ${ }^{\mathrm{d}}$ give you such a history of my doings, it $\mathrm{w}^{\mathrm{d}}$ be hard to say) from such facts, as the relationship between the living \& extinct mammifers in S. America, \& between those living on the continent $\&$ on adjoining islands, such as the Galapagos-It occurred to me, that a collection of all such analogous facts would throw light either for or against the view of related species, being co-descendants from a common stock. (Darwin 1844).
It is worth considering this passage here (albeit anachronistically) primarily because Darwin lays bare the true significance of what he, in "February 1835," says is Lyell's notion that species have deaths as well as do individuals. And the deaths — of species, as much as of individuals - can be understood to have underlying natural causes.

Thus, the 1835 passage is the first explicit mention Darwin makes of the analogy between the histories of individuals and the histories of entire species. Lyell, recall, felt that the extinctions of species were "appointed"-i.e., known to the Creator in advance - but that nonetheless extinction of any given species is through natural causesmost usually through environmental change. Darwin in 1835 is taking a hard look at the full analogy: even though the Creator may know in advance of the births and deaths of individuals, nonetheless such events have natural causes. Likewise for species - especially (and less controversially) their deaths - as this already is Lyell's position.

But if it is not Lyellian climate-change that causes extinction, what caused those species of large fossil mammals to disappear? Here Darwin, this time not citing Lyell by name, in his note "(a)," harks back to two passages in Lyell's second volume (see also Hodge 1983). In his chapter on extinction, Lyell discusses the ideas of the Italian geologist Giovanni Battista Brocchi (1814), who, like Lyell, rejected cataclysms to account for species extinction; as Lyell wrote:

...Brocchi endeavoured to imagine some regular and constant law by which species might be made to disappear from the earth gradually and in succession. The death, he suggested, of a species might depend, like that of individuals, on certain peculiarities of constitution conferred on them at their birth, and as the longevity of the one depends on a certain force of vitality, which, after a period, grows weaker and weaker, so the duration of the other may be governed by the quantity of prolific power bestowed upon the species, which, after a season, may decline in energy....and so all dies with it. (Secord, p. 255).

Lyell, respectfully, but nonetheless decisively, rejects "Brocchi's analogy" (as Rudwick 2008, p. 265, has aptly called it) of the deaths of species with those of individuals due to their supposed innate longevities - in favor, of course, of seeing extinctions as caused by external, physical events (such as climate change) - though without seeing extinctions as coming in massed events caused by cataclysms (in which he, Brocchi-and now, Darwin agreed).

But Darwin has ruled out environmental causes for the extinctions of his large mammals. And so, without mentioning him by name, he considers - with favorBrocchi's idea of innate species longevities when he writes [in note "(a)"] that if species existence "each according to 
its kind" "be allowed," then deaths would be staggered, and a more or less constant diversity of life through the geological epochs would ensue, as a matter of course, "as the Author of Nature has now established." Recall that Lyell saw the diversity of life as virtually in a steady state.

And how can we be sure that "each according to its kind" really does refer to innate longevities of species, by analogy with individuals? By the preceding sentence and a half of that same note "(a)." And this too is a riff on-and rejection of - another Lyell passage - this one from Lyell's (1832) second chapter of his second volume entitled "Transmutation of Species Untenable":

The propagation of a plant by buds or grafts, and by cuttings, is obviously a mode which nature does not employ; and this multiplication, as well as that produced by roots and layers, seems merely to operate as an extension of the life of the individual, and not as a reproduction of the species, as happens by seed. (Secord 1997, p. 207).

Darwin begs to differ. He says he is aware the analogy "is a false one," but in considering the increase in longevity of individual plants through grafting - and especially in the phrase "all these thousand trees are subject to the duration of life which one bud contained," he is directly alluding to what we would now call the genetically based longevity of an individual organism. Grafting was the proof to these early naturalists that individual organisms indeed have innate longevities.

Darwin is saying that he sees no reason why "generation" (reproduction) cannot also convey a natural "duration" (i.e., a "lifetime") to an entire species. But Darwin's analogy to grafting, in particular in using the phrase "enormous extension of life" of an individual plant, might also carry some transmutational overtones.

As we have seen, throughout his Vol. 2, Lyell is adamant about the "fixity" of species. Indeed, "species fixity" was perhaps the antonymic phrase for "transmutation." Lyell's own "litmus test" for transmutation came on the very first page of Vol. 2 of his Principles - in his first question, which asks "if species have a real and permanent existence in nature; or whether they are capable, as some naturalists pretend, of being indefinitely modified in the course of a long series of generations?"

If Darwin was indeed extending his grafting analogy to suggest that species' longevities might be extended through generation as the "enormous extension of life" is given to an individual through grafting, he would be admitting that an intrinsic property of a species can indeed be modified. Such a conclusion would, of course, trigger Lyell's "litmus test" for transmutation.

Thus the grafting analogy clearly stands as Darwin's argument for the plausibility of Brocchi's concept of innate species longevities. It is less clear that the "enormous increase" of individual plant longevities achieved through grafting also conveys a sense that species longevities themselves might be increased through natural processes.

But that is by no means all of the meaning of these few sentences from "February 1835" cited above. For now it becomes truly clear what he means when he cites, once again, the cavy he has been so obsessed with since Bahia Blanca. Once again, he says that he hopes it will prove to be another "small instance" "of at least a relation of certain genera with certain districts of the earth." He means he hopes cavies are endemic to South America.

And then he adds "this co-relation to my mind renders the gradual birth and death of species more probable." Why does he say that? The thought is explained in the final portion of the sidenote (a): "If the existence of species is allowed, each according to its kind, we must suppose deaths to follow at different epochs, \& then successive births must repeople the globe or the number of its inhabitants has Varied exceedingly at different periods. A supposition in contradiction to the fitness, which the Author of Nature has now established." Meaning: if each species has an innate longevity peculiar to it (i.e., not all species have the same innate longevities - as is the case with individual organisms), then births must follow deaths with regularity - or there would be drastic variations in levels of species diversity which (and here he totally agrees with Lyell) we know has not happened: Darwin is agreeing with Lyell that species diversity has remained more or less constant through the ages. Saying this is a dictate of the "Author of Nature" (a phrase used by Lyell and many other contemporary naturalists) is merely to cite the putative ultimate cause; otherwise there are natural ("secondary") causes for the deaths of species.

And for their births as well- though Darwin stops short of actually saying so. But he is specifying the pattern: that births of endemic, congeneric species follow soon after the deaths of predecessor species. The Bahia Blanca cavy example is crucial here (Brinkman, personal communication and 2003, has reached the same conclusion, [privately] calling the cavy the "smoking gun" in the development of Darwin's transmutational ideas). The cavy is the "just right" example, as the larger extinct edentate mammal species are less closely similar and more distantly related to the living species, and the fossil invertebrates seemed to Darwin to persist unchanged into the modern fauna (Fig. 5).

That's what Darwin is doing: specifying and constraining the patterns of births and deaths of species. As to his allusion to the "arguments he (i.e., Lyell) adduces," Darwin is likely referring to Lyell's comment (Secord 1997, p. 297) to the effect that perhaps in a century or two, naturalists encountering the fossils of still-living species might be able finally to shed some light on the secondary causes 
underlying the births of species. The passage is worth citing in full:

The observations of naturalists may, in the course of future centuries, accumulate positive data, from which an insight into the laws which govern this part of our terrestrial system [i.e. creation of new species] may be derived; but, in the present deficiency of historical records, we have traced up the subject to that point where geological monuments alone are capable of leading us on to the discovery of ulterior truths. To these, therefore, we must now appeal, carefully examining the strata of recent formation wherein the remains of living species, both animal and vegetable, are known to occur. We must study these strata in strict reference to their chronological order as deduced from their superposition, and other relations. From these sources we may learn which of the species, now our contemporaries, have survived the greatest revolutions of the earth's surface; which of them have co-existed with the greatest number of animals and plants now

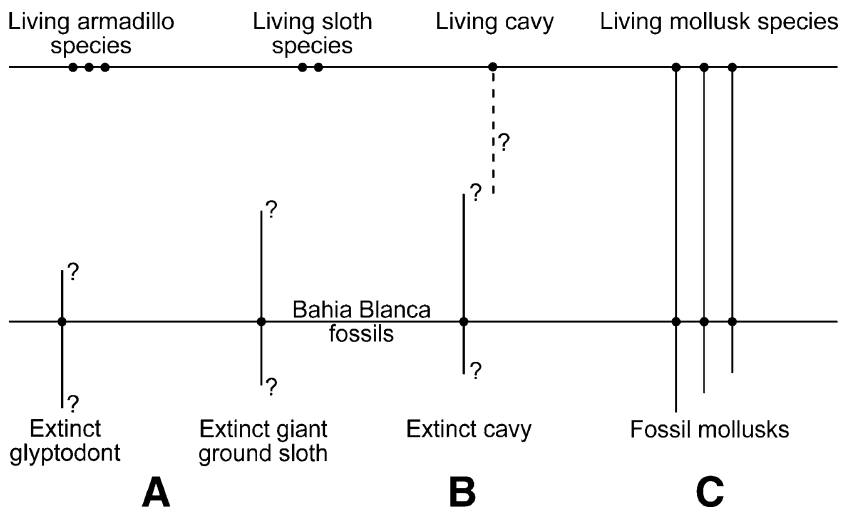

Fig. 5 The three patterns of relationship between fossil and living species at Bahia Blanca, Patagonia as Darwin explicitly saw them in "February 1835" - and as early as September/October 1832 when he was collecting the fossils and observing the local biota. Lower horizontal line indicates the fossil beds; upper line the recent. Times of origins and extinctions hypothetical but staggered to reflect Darwin's assertion that the births and deaths of species are "gradual." $A$ Two examples of extinct large edentate mammals (ground sloth and glyptodont) "allied with" modern sloths and armadillos, respectively. The dissimilarities in size and morphology between fossil and recent species are too great to suggest anything more than replacement of extinct species by other species in the same natural group. $C$ Darwin considered the fossilized shells of mollusks (and other invertebrates) in the Punta Alta beds to belong to the same species still extant in Bahia Blanca. In this instance, it is persistence, but not replacement, of fossil species into the modern biota. $B$ The intermediate case: Darwin considered his fossil cavy to be an extinct species closely allied to ("congeneric" with) the modern cavy which takes the place of the extinct relative. The birth of the modern species follows closely the extinction of the fossil cavy species-illustrating the general pattern that Darwin focused on in "February 1835" extinct, and which have made their appearance only when the animate world had nearly attained its present condition.

From such data we may be enabled to infer whether species have been called into existence in succession or all at one period; whether singly or by groups simultaneously; whether the antiquity of man be as high as that of any of the inferior beings which now share the planet with him, or whether the human species is one of the most recent of the whole. (Secord 1997, pp. 297-298).

How long had Darwin been thinking along these lines? One clue comes in March 1834, on his second trip to the Falklands, where he wrote the notes on the individuality of the Falkland fox species and remarked on how constant the differences between the foxes of East and West Falkland seemed to be. There he also wrote a letter to John Stevens Henslow (Darwin 1834b). After saying how happy he was to hear of the safe arrival of his "second cargo" of specimens, Darwin goes on to express anxiety on the way his specimens were being treated:

I have been alarmed by the expression cleaning all the bones, as I am afraid the printed numbers will be lost: the reason I am so anxious they should not be, is that a part were found in a gravel with recent shells, but others in a very different bed.-Now with these latter there were bones of an Agouti, a genus of animals I believe now peculiar to America \& it would be curious to prove some of the same genus coexisted with the Megatherium; such \& many other points entirely depend on the numbers being carefully preserved.My entire ignorance of comparative Anatomy makes me quite dependent on the numbers: so that you will see my geological notes will be useless without I am certain to what specimens I refer.

In a word, Darwin was keen to establish the contemporaneity of his fossil cavy specimens with the bones of the larger fossil mammals - which co-occurred with the fossil shells of what Darwin believed to be still-living species of marine invertebrates. Why? Because he thought he had an example of replacement of an extinct species of endemic rodent congeneric with the living species. And why would that be important?: for the light it sheds on patterns of births and deaths of species - perhaps going as far as shedding even more light on the secondary causes of the births of species.

And it is important to remember that Darwin voiced these very same concerns about the labeling of his fossil specimens from Bahia Blanca in October-November 1832 (Darwin 1832b) in an earlier letter to Henslow - and before he received Vol. 2 of Lyell's Principles. 


\section{March 1835-September 1835}

In March 1835, Darwin made his famous trek over the Andes through the Portillo Pass. He was later [e.g., in his Animal Notes written in mid-1836 (Darwin 1836a)] to declare Mendoza the "birthplace" of Patagonian species and to say (in his Journal of Researches, Darwin 1839, in a passage that was not merely copied from his Beagle Diary or scientific notes) that he had had his first thoughts on the similarities and differences of the faunas of the eastern and western slopes of the Andes on that trek. And in a famous footnote to that 1839 passage, he says that his comments on the distributions of Andean species of animals and plants "...is merely an illustration of the admirable laws first laid down by Mr Lyell of the geographical distribution of animals as influenced by geological changes. The whole reasoning, of course, is founded on the assumption of the immutability of species. Otherwise the changes might be considered as superinduced by different circumstances in the two regions during a length of time" (Darwin 1839, p. 400). The passage in the main text contains the phrase "unless we suppose the same species to have been created in two separate countries...."

There is, of course, no way of determining how much of these thoughts Darwin actually had in March 1835 while making the trek through the Portillo Pass-and historians generally agree that this 1839 passage is at most a sly hint of Darwin's by-then documented (i.e., in his "Red" and "Transmutation Notebooks") adoption of transmutation. On the other hand, Darwin, in this added passage, insists that these were his observations at the time he made the journey (i.e., "I was very much struck...."); and the "February 1835 " essay at the very least makes it clear that Darwin was well aware then of alternatives to Lyell's "assumption of the immutability of species."

Back on the Chilean Pacific coast, at Coquimbo, Darwin finds the best geological section he was to experience in western South America-where the layers of sediments laden with marine invertebrate fossils seem to him to reveal a sequence approaching modernity as one goes from bottom to top. But Darwin does not talk about the introduction of new species - nor the transformation of characters of the species. Rather, his notes are thoroughly Lyellian, as he discusses the increasing percentage of modern species as one collects progressively up the section. Again, uncertainty of the true geographic spread of these marine species is evidently enough to prevent Darwin from speculating further on the significance of the geological occurrence of these fossils.

Darwin wrote several family members from Lima in the summer of 1835 of his excitement about the Beagle's pending trip to the Galapagos Islands. He told a sister that he expected both the geology and zoology to be very interesting and said to his cousin William Fox that he hoped the geology would contain Tertiary strata. If so, there would be a chance to trace the development through time, and from island to island, of the fauna and flora of a place Darwin fully expected to be a varied version of the familiar South American biota - as he had already observed in the Falklands and the Chonos Archipelago. He was to be disappointed in his quest for Galapagos Tertiary sedimentary rocks and fossils; but, of course, the flora and fauna did not disappoint.

\section{On the Galapagos: September-October 1835}

That Darwin came to the Galapagos with a mind fully prepared to find variation - not only of the species from their closest relatives on the South American mainland but also variation from island to island as closely "allied" forms replace one another-is evident from the notes he made while he was actually there (for little over one monthSeptember 15-October 20th, 1835).

Darwin found this pattern of replacement-withinreplacement with the mockingbirds. As he wrote in his notes while still in the Galapagos:

This birds [sic] which is so closely allied to the Thenca of Chili (Callandra of B. Ayres) is singular from existing as varieties or distinct species in the different Is ${ }^{\mathrm{ds}}$ - I have four specimens from as many Is ${ }^{\mathrm{ds}}$ - These will be found to be 2 or 3 varieties-Each variety is constant [emphasis added] in its own Island.... This is a parallel fact to the one mentioned about the Tortoises. (Darwin 1835b).

That Darwin was actually looking for this double pattern of replacement that he found in the mockingbirds and soon after learned of in the tortoises is perhaps even more graphically confirmed by what Darwin, famously, did not see in the Galapagos: any pattern of inter-island replacement by "varieties or species" of the Galapagos finches. It has become a commonplace to speak of Darwin's failure to systematically collect these birds and especially his supposedly mysterious failure to keep accurate labels on the finches he did collect on the various different islands-as an inexplicable aberration, a departure from his training with Henslow, and for that matter from all his careful collecting procedures prior to arriving in the Galapagos in the nearly 4 years of the Beagle's voyage up to that point.

A simpler explanation leaps out from Darwin's notes on the finches while he was there: on each island, the core group of what are now called the "ground finches" presents a confusing mélange of variation that is more or less the same on each island he visited:

Far the preponderant number of individuals belongs to the Finches \& Gross-beaks-There appears to be 
much difficulty in ascertaining the Species. (Keynes 2000, p. 297).

That was the best he could do with the finches; they certainly did not present the easily seen sort of patterns of constancy of one variety or species on one island, replaced on an adjacent island by a related, but easily distinguished, form. Nor has all the celebrated work-starting with London ornithologist John Gould when Darwin brought his specimens back - really shown otherwise. The purport of Gould's analysis was that all these "finches and Grossbeaks" form a single group of 12 "allied" species of a single, natural group-one that is endemic (with the exception of the Cocos finch) to the Galapagos. The picture is one of an adaptive radiation in beak morphologyimportant, to be sure, but not the pattern Darwin went to the Galapagos looking for: the replacement of closely similar taxa (species or varieties) on different islands.

Darwin's rewritten and augmented notes on the ornithology, mammalogy, and entomology of the specimens he had seen and collected on the trip — written near the trip's end (i.e., summer 1836), as the Captain was making some final coastal measurements in Brazil-are fraught with transmutational hints. But the best-known passage - in the section devoted to the mockingbirds of the Galapagos in his Ornithological Notes (Barlow 1963; Kohn et al. 2005) — is where Darwin explicitly links the patterns of inter-island replacement of allied varieties or species, all of which retain distinct affinities with mainland species - with transmutation. After repeating the contents of his previous notes, Darwin adds:

In each Isld. each kind is exclusively found: habits of all are indistinguishable. When I recollect, the fact of the form of the body, shape of scales \& general size, the Spaniards can at once pronounce from which Island any Tortoise may have been brought. When I see these Islands in sight of each other, \& possessed of but a scanty stock of animals, tenanted by these birds, but slightly differing in structure \& filling the same place in Nature, I must suspect they are only varieties. The only fact of a similar kind of which I am aware, is the constant/asserted difference-between the wolf-like Fox of East and West Falkland Islds.-If there is the slightest foundation for these remarks the zoology of Archipelagoes-will be well worth examining; for such facts \{would inserted\} undermine the stability of Species. (Barlow 1963, p. 262; emphasis added).

Before the Captain had made his mad dash back across the southern Atlantic, the Beagle had called at Cape Town in June 1836. There Darwin had visited John Herschel, renowned British astronomer and figure in the British scientific establishment. In February of 1836, Herschel had written Lyell about his disappointment that Lyell had not tackled the "mystery of mysteries"-by which Herschel meant "the replacement of extinct species by others." Herschel went on to say that "we are led, by all analogy, to suppose he [i.e., the Creator] operates through a series of intermediate causes." Whether or not Darwin and Herschel touched on these matters in their conversation a few months later is not known. But no matter: Darwin had clearly reached the same conclusion a full year earlier in "February 1835 " - if not before. And of course it was Herschel who was "one of our greatest philosophers" to whom Darwin alluded in the opening words of the Origin cited at the inception of this essay.

In the waning months of the Beagle voyage, Darwin opened up a red-colored notebook stamped RN and proceeded to record desultory latitude and longitude readings, memos to himself about his readings - and observations on islands the Beagle stopped in on in the last few months of the trip. These little snippets are fraught with transmutational interest (Hodge 1983; D. Kohn, personal communication).

But it was not until sometime after the Beagle finally reached home in October 1836 that Darwin returned to the "Red Notebook," (Darwin 1836-37) flipping it around now to be written in as a book (he had been writing vertically on the pages while on the Beagle). The best estimate is that it was not until March of 1837 that he was able to find the time to record his further thoughts and reflections on what he had seen while on that long Beagle journey.

And here, as mentioned, we have "February 1835" all over again, augmented by more and somewhat different examples and integrated now with his focus on replacement patterns of allied, endemic forms in space and time that had been his trademark since the inception of the journey-and the source of his famous transmutational remark in the Ornithological Notes. And, of course, by now the cat is fully out of the bag: Darwin, though still writing for his own eyes only, is an out-and-out admitted transmutationalist.

Darwin turns to the rheas, writing that there is no "progressive" change as one approaches the area (at the Rio Negro) where their ranges overlap. His first openly recorded thoughts on transmutation literally involve the replacement of one species by another, descendant species by a process of rapid ("saltational") transformation. He then reiterates the core of his transmutational idea in "February 1835 " as he writes that the extinct llama (his Port St. Julian "Mastodon" had been-erroneously-re-identified by Richard Owen as a camel) "owed its death not to change of circumstances; reversed argument. Knowing it to be a desert. Tempted to believe animals created for a definite time:- not extinguished by changed circumstances" (Herbert 1987 , p. 62) - the latter point a return to Brocchi's views apparently originally learned from Lyell's Vol. 2. "February $1835 "$ all over again. 
He goes on to say that replacement in space (geography) is the same sort of phenomenon as replacement in time: "The same kind of relation that common ostrich bears to Petiise...extinct Guanaco to recent: in former case position, in latter time..." (Herbert 1987, p. 62). (Owen identified Darwin's fossil cavy from Monte Hermoso as, in fact, a tuco-tuco - a group of species of South American rodents belonging to a different lineage than cavies. As a result, Darwin never mentions his cavy again). And the change from one species to another is all per saltum - by sudden jumps-not gradual.

And then Darwin returns to the analogy between the individuals and species he presumably first encountered in Lyell, who rejected it, and which he first explored, albeit cryptically, in "February 1835." He writes: "There is no more wonder in extinction of species than of individuals."

By now, the analogy is complete: Just as individuals have births and deaths, explicable by intermediary causes (i.e., however much God may be the mastermind of everything), so too do species have births and deaths, explicable through natural, intermediary causes.

Darwin came to evolution pretty much as he said he did - in several passages in his writings - including the sentences from the beginning of the Origin, from his Autobiography, and the letters he wrote Jenyns (cited above) and Joseph Hooker in 1844. He was looking for a natural, "secondary" causal explanation for the births of speciesone that would complete the analogy between the births and deaths of individuals (for no matter how much the Creator might be involved in the births and deaths of individual humans, there were also known biological causes for those births and deaths); and naturalists openly argued over the correct explanation of the extinction of species. What was missing was a natural causal explanation for the births of species.

But some obvious questions remain. In particular, why did Darwin focus on patterns of replacement of closely related species in time? Why did he use the word "passage" when comparing the tail anatomy of his Bahia Blancan fer-de-lance to those of adders and rattlesnakes? Why a focus on endemic natural groups? Where did this all come from?

\section{Before the Beagle}

Darwin's work on the Beagle reads like a long, deliberate experiment. His first theory of evolution-not expressed explicitly until he finished his thoughts in the "Red Notebook" as he reconsidered his Beagle experiences and his more subtly expressed ideas in his essay "February 1835 ," speaks of the births of species, and is saltational: Darwin could not document the "smear" in variation that
Lamarck had said would be the pattern nature would present if transmutation were "true": i.e., with good data, species would intergrade gradually both in time (as one species transforms into another, descendant species) and in space (as one species blends into another geographically). The cavies are distinct, albeit closely related species, the modern species replacing the extinct fossil species. The rheas, not all that dissimilar from one another, do not blend into one another when their ranges overlap at Patagonia's Rio Negro. And, as a theoretical expectation, accepting Brocchi's premise that species have innate longevities, the births of new species closely on the heels of the deaths of close relatives is arguably as discrete a process as the birth of an individual metazoan from its mother.

Darwin, as is well known, knew about transmutation from his grandfather Erasmus' book Zoonomia (E. Darwin 1794-96). And, as is also well known, Darwin worked with invertebrate zoologist Robert Grant while he was a medical school student in Edinburgh. As Darwin recorded in his Autobiography, one day Grant burst forth in a paean of praise of Lamarck's transmutational ideas. Darwin wrote:

I listened in silent astonishment, and as far as I can judge without any effect on my mind. I had previously read the Zoonomia of my grandfather, in which similar views are maintained, but without producing any effect on me. Nevertheless it is probable that the hearing rather early in life such views maintained and praised may have favoured my upholding them under a different form in my Origin of Species. (Barlow 1958, p. 49).

Other than these few words, suggestive as they are, the trail goes cold - at least from Darwin's own lips - on what he might have heard, seen or read that might have suggested to him where and how to look for the very patterns that ultimately took him to transmutation. And though Darwin learned the essentials of geological mapping from Adam Sedgwick at Cambridge; and, as significantly, the importance of documenting variation in contemporary British plants from his other Cambridge mentor, John Stevens Henslow (Kohn et al. 2005), there is otherwise nothing to suggest that either of these scientists - known to be opponents of transmutation-had set Darwin in the direction of documenting patterns of endemic species replacement in space and time.

So where did the focus on replacement patterns among closely related endemic species come from-if indeed it came from anywhere other than Darwin's own fertile imagination? For, in my opinion, the cavy alone tells us that he was looking for such patterns and concerned his data would be lost, before he ever got to read Lyell's account of Lamarck's transmutational ideas.

One possibility presents itself: an anonymous essay entitled "Observations on the Nature and Importance of 
Geology," published in October 1826 in Vol. 1 of the Edinburgh New Philosophical Journal-as Darwin was beginning his second year in medical school. According to Darwin (Barlow 1958, p. 50), the journal's editor, the mineralogist Robert Jameson, was involved with the student-run Plinian Society-where students met and read papers on their scientific work. Jameson also gave lectures on geology and zoology, which Darwin attended in that second year, and which, in his Autobiography (Barlow 1958, p. 52), he dismissed as "incredibly dull."

Apparently first noted by anthropologist Loren Eisley (1958) among modern Darwinists, the few Darwin scholars who have considered this anonymous text (e.g., Desmond 1984; Secord 1991; Browne 1995) have disagreed on who its author might have been. Given Robert Grant's fame as an early proponent of Lamarck, suspicion naturally first fell on him as the probable author; but Secord (1991) has made a strong case that it was Jameson himself who must have written this essay.

Browne (1995, p. 81) wrote: "In the same year, Grant seems to have gone even further in producing an anonymous essay boldly advocating a similar kind of evolutionary progress in living beings generally, more or less an extension of Lamarck's scheme of transmutation. The article carried the distinction of being the first significant statement linking Lamarck's scheme with the geological history of living beings." In a footnote, she acknowledges Secord's argument that it may have been Jameson, not Grant, who authored the paper - but adds that "Despite the material produced as evidence in the latter case, it seems more likely that this came from some third party, not directly from Jameson's pen." Desmond and Moore (1991, p. 40), agreeing that Jameson was the author of the anonymous piece (as does Rudwick 2008, p. 245, n. 11though with some equivocation), also add that the word "evolved" in the modern sense first appears in this 1826 essay. And, as my colleague H.B. Rollins points out (personal communication), the passage in this essay bearing on the origin of granite is redolent of the Wernerian convictions for which Robert Jameson was so well known.

There is no evidence directly linking Darwin with this essay: To my knowledge, Darwin never mentioned it, nor is there a copy present in Darwin's surviving personal library (David Kohn, personal communication). Yet, Browne (1995, p. 85) could well be correct in stating that "He (i.e., Darwin) read articles in the Edinburgh New Philosophical Journal, probably including the anonymous evolutionary essay of 1826."

And what an essay this "Observations on the Nature and Importance of Geology" turns out to be. The full text is available online at http://www.biodiversitylibrary.org/title/ 00369casxa2200121xxx4500. The author speaks admiringly of Lamarck ("one of the most sagacious naturalists of our day") - though also admonishes the reader to be aware of Lamarck's speculative proclivities: "it should not be forgotten, that this meritorious philosopher, more in conformity with his own hypothesis than is permitted in the province of physical science, has resigned himself to the influence of imagination, and attempted explanations, which, from the present state of our knowledge, we are incapable of giving."

The author paints a convincing picture of the earth essentially unchanging in its basic physical characteristicsan immanence that stands in stark contrast with the complexification and diversification of life through geological history. And the author points out, as well, that the basic history of life as then known through the fossil record accords very well in general outline to what might be expected had life evolved through time:

The doctrine of petrifactions, even in its present imperfect condition, furnishes us with accounts that seem in favour of Mr Lamarck's hypothesis. We, in fact, meet with the more perfect classes of animals, only in the more recent beds of rocks, and the most perfect, those closely allied to our own species, only in the most recent; beneath them occur granivorous, before carnivorous, animals [Lyell's point!]; and human remains, are found only in alluvial soil, in calcareous tuff, and in limestone conglomerates. (Anonymous 1826, p. 297).

But, as Browne suggests, it is the linkage of Lamarck's transmutational ideas with geology - and specifically with the anonymous author's analysis of what should be observed in the fossil record ("Laws of Petrifactions") should Lamarck's transmutational ideas be correct, that show us where Darwin might possibly have gotten his inspiration to focus on patterns of replacement of "closely allied," "congeneric" species in time as well as in space. For here in this short essay of 1826 is made mention of (1) explanations of extinction, replacement, and transmutation in terms of "natural law"; (2) the importance of endemism; (3) the need to focus on higher organisms (e.g., mammals and birds rather than marine invertebrates) to reveal these patterns; (4) the apparent extinction of species as evidence for evolution; and (somewhat surprisingly) (5) the analogy between individuals and species in terms of births and deathsand even the supposition that species have internally constrained longevities.

The anonymous author deals with the apparent extinction of species in three distinct ways: First, they might not actually be extinct at all-but still alive and living elsewhere (as Darwin surmised, but then rejected, might 
be the case with South American ground sloths). But, secondly, they may have become extinct by transforming into a descendant species:

The distinction of species is undoubtedly one of the foundations of natural history, and her character is the propagation of similar forms. But are these forms as immutable as some distinguished naturalists maintain; or do not our domestic animals and our cultivated or artificial plants prove the contrary? If these, by change of situation, of climate, of nourishment, and by every other circumstance that operates upon them, can change their relations, it is probable that many fossil species to which no originals can be found, may not be extinct, but have gradually passed into others. As there are periodical movements of the heavenly bodies, that is, movements that are visible only after hundreds of years, so there are undoubtedly periodical changes in the organic world. If these have required intervals of time that are antecedent to all historical traditions, and to the duration even of the human race, the monuments concealed in the bosom of the earth can alone reveal them. (Anonymous 1826, p. 298-299).

It is the suggestion that species can, in effect, be turned into other species, creating the illusion of extinction, that calls to mind Darwin's fascination from the very beginning with the fossil cavy of Bahia Blanca-closely similar to, but not actually the same species as, the modern cavy.

And to that point - and remembering the salient features of Darwin's essay "February 1835," consider:

Geology does not inform us merely of the origin of animal species ${ }^{1}$, but also of their destruction. Out of the vast number of animal remains, but few belong to species now living, and these only, in the most recent rock-formations; by far the greater number of their primitive structures are lost, and the older the beds of rock in which they make their appearance, so much the more do they deviate in their formation from the species now in existence. May this destruction, as is commonly received, have been the result of violent accidents, and destructive revolutions of the earth or does it not rather indicate a great law of nature, which cannot be discovered by reason of its remote antiquity? Within the narrow circle of vision in which the organic world manifests itself to our observation, we observe individuals only going to destruction, and in opposition

\footnotetext{
${ }^{1}$ According to Desmond and Moore (1991, p. 42), Jameson's "closing lectures" in his course on natural history-a course Darwin tookwere called "on the 'Origin of Species of Animals'." Perhaps only coincidence.
}

to that, great preparations making for the preservation of the species.

The anonymous writer goes on:

But if all living perish, may no point of duration have been fixed for the species; or do we not rather, in these signs of a former world, discover a proof, that, from a change in the media in which organic creatures lived, and from powerful causes operating upon them, their power of propagation may be weakened, and at length become perfectly extinct? Is the continual decrease, then, which we observe among some species, a consequence of the various modes of destruction they experience from the hand of man, or may it not rather be produced by natural circumstances, and be a sign of the approaching old age of the species ? (Anonymous 1826, p. 297-298).

The anonymous author is suggesting a natural law for species - analogous with one for individuals - that there is an aging process to species that might account, along with missing data and transmutation of ancestral species into descendant, for the phenomenon of extinction (i.e., intrinsic aging of species is his third explanation for extinction within this essay). Brocchi, whose thoughts on the subject were reiterated, but rejected, by Lyell in Vol. 2 of the Principles (Lyell 1832), but were later adopted by Darwin with approval ("February 1835"; "Red Notebook"), published his version of these ideas in 1814 (Brocchi 1814) leaving the exact origin of this important line of thinking in this anonymous essay of 1826 a matter for further research.

But then, there is the matter of endemism, another key element of Darwin's pre-Lyellian thinking at Bahia Blanca and throughout the remainder of the Beagle journey. The anonymous author writes:

Geology likewise supplies us with instructive disclosures regarding the distribution of organic beings. If we, in all the regions and climates of the world, meet with a striking uniformity in the structure of the earth, we also, on the contrary, observe plants and animals of a most varied character scattered over its surface. As there are among the dicotyledons, that is, among the more perfect plants, no species, which are at the same time indigenous to the hot climates of the old and new world, so both halves of the globe in the same zone possess mammiferous animals, birds, reptiles, and insects peculiar to each. Species common to both are found only among the inferior gradations of organization, and species of a higher order are found only in those high northern latitudes, where the continents were undoubtedly at one time conjoined. (Anonymous 1826, 299). 
Geographical differentiation (through transmutation) is most marked and best observed in the "higher orders" of life - so one would naturally look to mammals and plants, rather than, say, marine invertebrates, for the evidence. Recall that Darwin did precisely that-though possibly simply because he could not be sure of the biogeography of his extant marine invertebrates species-including those with hard shells that he persistently found in the fossil record. It is perhaps also worth noting that Darwin himself used the expression "peculiar to" when referring to the South American endemic status of cavies, endentates, and other natural groups.

Browne (1995) also reports that Grant gave Darwin copies of his (Grant's) papers on marine zoology published that same year in that same Edinburgh volume (there were four of them) and that Darwin read them "almost as if collecting all possible points of view about transmutation and secular science in general." (Browne 1995, p. 85). In one of those papers, Grant (1826) wrote about his new genus Cliona, which he proclaimed had a combination of properties providing the connection (Grant 1826, p. 81) between Alcyonium and sponges - with what we know was a transmutationist perspective firmly in mind. When Darwin was at Bahia Blanca, besides the cavy and large edentate fossil bones, he remarked on the inosculating admixture of a bird half-way, he thought, between a snipe and a "lark-pidgeon." And he wrote, of course, about the tail of the local fer-de-lance-with the simple, hard terminus of its tail "marking the passage" between adders, on the one hand, and rattlesnakes, on the other.

Other naturalists, of course, were making similar observations. But as to the question: where did Darwin pick up the idea that he might focus on patterns of replacement of closely "allied" endemic species in time and in space? Why the focus on terrestrial mammals and birds rather than the marine invertebrates familiar to him from his early work with Grant? And where did the notion that some taxa share a mixture of features of other groupsor that sometimes anatomical features of one group appear to be intermediate between two other groups - come from?

It would seem that Browne (1995) and others might be right when they point to Robert Grant, Robert Jameson, and perhaps others in Edinburgh, staunch Lamarckian transmutationists, as having provided more background and details on transmutational thinking than has usually been acknowledged. And it hardly seems possible that all of this would have been lost on Darwin.

Quite the reverse: it now seems to me unlikely that Darwin would have approached his cavy, his giant armadillo, his Megatherium, or his fer-de-lance at Bahia Blanca in September and October 1832 the way he did unless he had been steeped in the thinking along the lines represented in this anonymous essay of 1826 - and in the general approach to invertebrate zoology he learned at the very side of Robert Grant.

\section{Conclusion}

In suggesting that Darwin might well have gotten his focus on replacement patterns of "closely allied" (congeneric) endemic species, in time and space, from his Edinburgh experiences, possibly including the anonymous essay of 1826, I am not saying that Darwin was a transmutationist before he embarked on the Beagle in late 1831. Indeed, when Darwin "became" a transmutationist is impossible to tell-if there was really such a singular point in time at all.

But Darwin's work on the Beagle has all the earmarks of an experiment and a well-thought-out one at that. If, as is commonly said, the Origin of Species is "one long argument," Darwin's biological and paleontological analytical work on the Beagle was "one long experiment." One would not come to an acceptance of transmutation, after all, by thinking in the ecological terms of someone like Charles Lyell — who saw births and deaths of species as unrelated to each other-taking place on average once a year in different ecosystems and with prey species necessarily appearing before predators.

Darwin seemed to be looking for replacements of closely similar and "allied" species in space and in time as if he were looking for that intergradational "smear" predicted by Lamarck's view of transmutation. He was doing this at Bahia Blanca before he received Lyell's Vol. 2-suggesting he had some thoughts along these lines for some time.

Darwin never found Lamarck's "smear." Perhaps the closest he came was when he spoke of the intermediacy of tail morphology of his fer-de-lance at Bahia Blancaemulating Grant's Lamarckian-imbued analysis of the sponge Cliona. Instead, Darwin's data approached Lamarck's smear only as a limit. He continued to see the problem instead as a matter of discrete births and deaths of species - analogous with the births and deaths of discrete individuals - all the way through the latter part of the "Red Notebook," with some saltational musings lingering into his "Transmutation Notebooks" that followed shortly thereafter (Eldredge 2005).

That he later abandoned saltation for a Lamarck-like emphasis on smooth, gradual intergradation - developed only after he had discovered an evolutionary mechanism-natural selection - is of course another story.

But to suggest that Darwin may have had predecessors and influences while he was a bored medical student in Edinburgh-predecessors who may have told him of Lamarck and transmutation and offered their own thoughts (as developed, e.g., in the anonymous essay of 1826) - is to take nothing away from Darwin's originality and achieve- 
ment. Rather, it humanizes him: no one, after all, works in a vacuum.

Acknowledgments I am deeply grateful to my friend and colleague, Dr. David Kohn, Drew University, guiding light of the Darwin Digital Library at the American Museum of Natural History. David taught me how to read Darwin and led the way in our two weeks study of Darwin's notes at the Cambridge University Library in early 2006. He also provided the transcriptions of the St. Jago and Bahia Blanca passages included herein. Though I alone am responsible for the conclusions drawn in this essay, David's influence permeates these pages. Special thanks go to Dr. Paul Brinkman, North Carolina Museum of Natural Sciences - whose analysis of Darwin's paleontological work, including the central importance of the cavy in Darwin's development of his transmutational ideas-preceded my own. That we agree on the essential elements and significance of the story of Darwin's paleontological work on the Beagle is deeply gratifying. I am also grateful for Dr. Brinkman's careful review of an earlier draft of this manuscript. I am grateful, too, to my paleontological colleague Dr. Gilbert Klapper of Northwestern University, who first brought the anonymous essay of 1826 to my attention, and for his discussions and comments on Darwin's Beagle work. Paleontologist Dr. Harold B. Rollins (University of Pittsburgh) has provided enormous stimulation and encouragement over the years - and has reviewed several drafts of this essay, helping me to sort out issues and make things clearer. I also thank Drs. Bruce Lieberman (University of Kansas), John N. Thompson (UC Santa Cruz), David Sepkoski (UNC Wilmington), Dan Brooks (University of Toronto), and Daniel Fernandez (CADICCONICET, Ushuaia) for their sentient and sometimes trenchant comments on earlier drafts of this paper. Thanks go as well to Dr. Teresa Manera (Universidad Nacional del Sur) for advice on the identity of Darwin's snake and to Dr. Pedro H. Bernardo (Museo de Zoologia, Universidade de São Paulo) for graciously permitting me to use his photograph of B. alternatus in Fig. 2. And thanks to Steve Thurston (American Museum of Natural History) for his great work scanning Fig. 1 and drawing Fig. 5. I am grateful, too, to the Division of Paleontology, The American Museum of Natural History, for partial support of my stay in Cambridge (UK) in 2006, and to Dr. Michael Rosenbluth, for his financial support and encouragement that has enabled me to pursue my quest to understand the origin of Darwin's evolutionary thinking, its connections with paleontology, and its relevance to modern evolutionary thought.

\section{References}

Anonymous. Observations on the nature and importance of geology. Edinburgh New Philos. J. 1826;1:293-302. http:// www.biodiversitylibrary.org/title/00369casxa2200121xxx4500; 1826.

Barlow N. The autobiography of Charles Darwin, 1809-1882. New York: Norton; 1958.

Barlow N. Darwin's Ornithological notes. Bull. Brit. Mus. (Nat. Hist.) Historical Series Vol. 2, no. 7. London; 1963.

Brinkman P. The Beagle voyage and fossil vertebrate succession. J Vert Paleont 2003;23:36a.

Brocchi GB. Conchologia fossile subapennina con osservazione geologiche sugli Apennini e sul suolo adiacente. Milan: 2 Volumes; 1814.

Browne J. Charles Darwin. Voyaging. Princeton: Princeton University Press; 1995.

Darwin C. Geological notes. Cambridge (UK): Darwin Archive, Cambridge University Library; 1832a. DAR 32.1: 34 St. Jago: 20.
Darwin C. Letter 192-Darwin, C. R. to Henslow, J. S., [26 Oct-] 24 Nov 1832. Darwin Correspondence Project, Cambridge University. http://www.darwinproject.ac.uk/darwinletters/calendar/entry-192. $\mathrm{html} ; 1832 \mathrm{~b}$.

Darwin, C. Geological notes. Cambridge (UK): Darwin Archive, Cambridge University Library. BAHIA BLANCA 1832.10-11 DAR 32.1: 62 ff. Coast of Patagonia: 50 [September-October 1832]; 1832c.

Darwin C. Reflection on reading my geological notes. DAR 42:49-52 + 73. Cambridge (UK): Darwin Archive, Cambridge University Library; 1834a. See Herbert, 1995, for transcription.

Darwin C. Letter 238 - Darwin, C. R. to Henslow, J. S., Mar 1834. Darwin Correspondence Project, Cambridge University. http://www. darwinproject.ac.uk/darwinletters/calendar/entry-238.html; 1834b.

Darwin C. February 1835. Dar $42+97-102$. Cambridge (UK): Darwin Archive, Cambridge University Library; 1835a.

Darwin C. Galapagos field notebook. Down House, UK; 1835b.

Darwin C. Animal notes. Cambridge (UK): Darwin Archive, Cambridge University Library; 1836a.

Darwin C. Ornithological notes. Cambridge University Library Handlist, No. 29ii; 1836b. See Barlow, 1963 for transcription.

Darwin C. Red Notebook. Down House, UK; 1836-37. See Herbert, 1987 for transcription.

Darwin C, editor. Birds Part 3 No. 1 of The zoology of the voyage of H.M.S. Beagle. by John Gould. Edited and superintended by Charles Darwin. London: Smith Elder and Co; 1838.

Darwin C. Journal of researches into the natural history and geology of the countries visited during the voyage round the world of $\mathrm{H}$. M.S. Beagle. London: Henry Colburn; 1839.

Darwin C, editor. Fossil Mammalia Part 1 No. 4 of The zoology of the voyage of H.M.S. Beagle. By Richard Owen. Edited and superintended by Charles Darwin. London: Smith Elder and Co.; 1840.

Darwin C. Letter 793 - Darwin, C. R. to Jenyns, Leonard, 25 [Nov 1844]. Darwin Correspondence Project, Cambridge University. http://www. darwinproject.ac.uk/darwinletters/calendar/entry-793.html; 1844

Darwin C. On the origin of species by means of natural selection. Or the preservation of favoured races in the struggle for life. London: John Murray; 1859.

Darwin, E. Zoonomia. Or the laws of organic life. 2 vols., London; 1794-1796.

Desmond A, Moore J. Darwin. The life of a tormented naturalist. New York: Warner Books; 1991.

Desmond A. Robert E. Grant: the social predicament of a preDarwinian transmutationist. J Hist Biol 1984;17:189-223. doi:10.1007/BF00143732.

Eisley L. Darwin's century. New York: Doubleday; 1958.

Eldredge N. Darwin. Discovering the tree of life. New York: Norton; 2005.

Grant RE. Notice of a New Zoophyte (Cliona celata, Gr.) from the Firth of Forth. Edinburgh New Philos. J. 1826;1:78-81. http:// www.biodiversitylibrary.org/title/00369casxa2200121 xxx4500; 1826

Herbert S, editor. Red Notebook. In Barrett, P.H., P.J. Gautrey, S. Herbert, D. Kohn and S. Smith (eds.). Charles Darwin's Notebooks. 1836-1844, pp. 17-81. Ithaca: Cornell University Press; 1987.

Herbert S. From Charles Darwin's Portfolio: an early essay on South American geology and species. Earth Sci Hist 1995;14:23-36.

Herbert S. Charles Darwin, geologist. Ithaca: Cornell University Press; 2005.

Hodge MJS. Darwin and the laws of the animate part of the terrestrial system (1835-1837): On the Lyellian origins of his zoonomical explanatory program. Stud Hist Biol 1983;6:1-106.

Keynes RH, editor. Charles Darwin's Beagle Diary. Cambridge (UK): Cambridge University Press; 1988.

Keynes RH, editor. Charles Darwin's zoology notes and specimen lists from H. M. S. Beagle. Cambridge (UK): Cambridge University Press; 2000. 
Kohn D, Murrell G, Parker J, Whitehorn M. What Henslow taught Darwin. Nature 2005;436:643-5. doi:10.1038/436643a.

Lyell C. Principles of Geology, Vol. 1. London: Murray; 1830. See Secord, 1997 for citations.

Lyell C. Principles of Geology, Vol. 2. London: Murray; 1832. See Secord, 1997 for citations.

Rudwick MJS. The great Devonian controversy. Chicago: University of Chicago Press; 1985.
Rudwick MJS. Worlds before Adam. Chicago: University of Chicago Press; 2008

Secord JA. Edinburgh Lamarckians: Robert Jameson and Robert E. Grant. J Hist Biol 1991;24:1-18. doi:10.1007/BF00130472.

Secord JA, editor. Charles Lyell. Principles of Geology. London: Penguin Books; 1997.

Sulloway FJ. Darwin's conversion: The Beagle voyage and its aftermath. J Hist Biol 1982;15:325-96. doi:10.1007/BF00133143. 